\title{
DESIGN AND IMPLEMENTATION ISSUES IN SWEDISH INDIVIDUAL PENSION ACCOUNTS
}

\author{
R. Kent Weaver* \\ CRR WP 2005-05 \\ Released: April 2005 \\ Draft Submitted: March 2005 \\ Center for Retirement Research at Boston College \\ 550 Fulton Hall \\ 140 Commonwealth Ave. \\ Chestnut Hill, MA 02467 \\ Tel: 617-552-1762 Fax: 617-552-0191 \\ http://www.bc.edu/crr
}

\begin{abstract}
* R. Kent Weaver is Professor of Public Policy and Government at Georgetown University and a Senior Fellow in Governance Studies at The Brookings Institution. The research reported herein was performed pursuant to a grant from the U.S. Social Security Administration (SSA) to the Center for Retirement Research at Boston College (CRR). The opinions and conclusions are solely those of the author and do not represent the opinions or policy of SSA or any agency of the Federal Government, the CRR, the Luxembourg Income Study, or the Brookings Institution.
\end{abstract}

(C) 2005, by R. Kent Weaver. All rights reserved. Short sections of text, not to exceed two paragraphs, may be quoted without explicit permission provided that full credit, including $\odot$ notice, is given to the source. 


\title{
About the Center for Retirement Research
}

The Center for Retirement Research at Boston College, part of a consortium that includes a parallel centers at the University of Michigan and the National Bureau of Economic Research, was established in 1998 through a grant from the Social Security Administration. The goals of the Center are to promote research on retirement issues, to transmit new findings to the policy community and the public, to help train new scholars, and to broaden access to valuable data sources. Through these initiatives, the Center hopes to forge a strong link between the academic and policy communities around an issue of critical importance to the nation's future.

\author{
Center for Retirement Research at Boston College \\ 550 Fulton Hall \\ 140 Commonwealth Ave. \\ Chestnut Hill, MA 02467 \\ phone: 617-552-1762 fax: 617-552-0191 \\ e-mail: crr@bc.edu \\ http://www.bc.edu/crr
}

\section{Affiliated Institutions:}

American Enterprise Institute

The Brookings Institution

Center for Strategic and International Studies

Massachusetts Institute of Technology

Syracuse University

Urban Institute 


\begin{abstract}
:
Sweden's new multi-pillar pension system includes a system of mandatory fully-funded individual accounts. The Swedish system tries to keep administrative costs down through centralized management of the collection of contributions, switching among fund options, and record-keeping and communication with account holders.

The Swedish system offers contributors more than 600 fund options. However, in the most recent rounds of fund choice, more than 90 percent of new labor market entrants have not made an active choice of funds, and thus have ended up in a government-sponsored default fund.

The Swedish system of individual accounts offers a number of lessons for countries considering adoption of a mandatory individual account tier. First, centralized administration of record-keeping, communication and trading functions can help to keep administrative costs down. Second, the lead time needed to set up such a system is considerable. Third, if entry barriers for funds are low, a very large number of fund options are likely to be offered. Fourth, engaging new labor market entrants in fund choice is likely to be difficult, and these barriers are likely to be particularly high for some groups - notably those with limited incomes and low English language skills. Fifth, in the absence of entry barriers for funds, a significant percentage of those making an active fund choice may choose funds that are very specialized and risky. Finally, the likelihood of limited active fund choice means that special care must be devoted both to the design of a default fund and to communicating to potential participants what asset allocation and risk-return trade-offs the default fund is likely to make.
\end{abstract}




\title{
Design and Implementation Issues in Swedish Individual Pension Accounts ${ }^{1}$
}

\author{
R. Kent Weaver \\ Georgetown University and The Brookings Institution
}

Some form of individual accounts remain one of the primary options for restructuring the Old Age and Survivors Insurance program, more commonly known as Social Security. President Bush's Social Security reform commission recommended adding an individual accounts component as a partial opt-out in the Social Security system, although they suggested several options rather than a single proposal.

Individual accounts pose a number of important and complex design and implementation issues, however. Who should administer the collection of contributions? How active a role should government play in certifying or regulating fund options? How active and risky an investment policy should qualifying funds be allowed to pursue? Should any restrictions be placed on foreign investment by fund managers? Particularly where individual accounts are mandatory rather than optional, what should be done about those who, for whatever reason, do not choose a fund manager? Should a fund for non-choosers minimize risk or attempt to stress enhanced returns necessary to provide an adequate retirement benefit?

An equally important set of issues arise in the design of benefit structures for individual accounts. Should government require full annuitization of personal account funds on retirement,

\footnotetext{
${ }^{1}$ The research reported herein was partially funded pursuant to a grant from the U.S. Social Security Administration (SSA) funded as part of the Retirement Research Consortium at Boston College. The opinions and conclusions are solely those of the authors and should not be construed as representing the opinions or policy of SSA or any agency of the Federal Government. The author would like to thank Annika Sundén for very helpful comments on an earlier draft of this paper.
} 
or should there be a more flexible set of payout options? How should retirees be protected from fluctuations in annuity prices that can arise in private annuity markets? Should annuity providers be able to charge higher prices to women than to men for annuities of equal value because women live longer on average? Should funds in individual accounts be inheritable?

As the debate on Social Security reform continues, much can be learned from the experience of Sweden, which added an individual accounts tier to its public pension system in the late 1990s. The Swedish system, called the premium pension, is quite distinctive in its design: 2.5 percent of payroll is deposited into an account managed by a fund manager chosen by employees from a list of funds approved by the new Premium Pension Authority (Premiepensionsmyndigheten, or PPM). In the initial round of sign- ups, workers could choose from 465 approved funds listed in PPM's fund catalogue, and were allowed to place their contributions into up to five different funds.

The new pension system that Sweden put in place in the late 1990s offers a possible model for a mandatory individual accounts pension tier that combines cost-lowering centralized administration with a very wide range of fund choice for individual contributors. This paper examines the Swedish experience and lessons it suggests about design and implementation challenges that are likely to arise in such a system.

\section{BACKGROUND TO REFORM}

Sweden has one of the oldest and most comprehensive public pension systems in the world. The state is clearly the dominant pension provider: in 1991, Swedes aged 66 and above 
received an average of 84.1 percent of their pension income from the state pension system, compared to only 13.5 percent from an occupational pension and 2.3 percent from a private pension. $^{2}$ The pension system is the largest government spending program. Pension spending increased from $4.3 \%$ of GDP in 1965 to $12.2 \%$ in 1992.

Prior to reforms enacted in the 1990s, Sweden's pension system consisted of a flat-rate basic pension and the national supplementary earning-related pension (ATP). The universal flatrate tier operated on a Pay-As-You-Go (PAYG) basis, while the earnings-related tier was partially pre-funded. Both tiers were financed largely by earmarked employer contributions. For retirees with few or no ATP pension credits, the basic pension system provided a flat-rate benefit while the ATP system provided income-related pensions calculated according to "defined benefit" principles. The system was designed so that the earnings-related pension would provide an average production worker with a replacement rate of 60 percent of income for the best 15 years of at least 30 years of labor market participation. Those above the system's benefit and contribution ceiling received no additional benefits for those earnings. ${ }^{3}$ In addition to the flatrate basic pension and earnings-related pension, a pension supplement equal to roughly half of the basic pension was available to individuals whose earnings-related benefits were very low. The pension supplement provided an income floor that, in combination with the other two tiers, moved almost all seniors in Sweden above poverty.

\footnotetext{
${ }^{2}$ Men received an average of 82 percent of their pension from the state pension system, while women got 86.9 percent of their (lower) pensions from the state. Eskil Wadensjö, "The Welfare Mix in Pension Provisions in Sweden," pp. 266-308 in Martin Rein and Eskil Wadensjo, eds., Enterprise and the Welfare State, Cheltenham UK and Lyme, CT: Edward Elgar, 1997, at p. 297. Palme and Svensson estimate that in 1994, 74 percent of the total income of persons over age 65 came from the state pension system. See Mårten Palme and Ingemar Svensson, "Social Security, Occupational Pensions, and Retirement in Sweden," pp. 355-402 in Jonathan Gruber and David A. Wise, Social Security and Retirement Around the World, Chicago and London: University of Chicago Press, 1999, at p. 355.

${ }^{3}$ See Mårten Palme and Ingemar Svensson, "Social Security, Occupational Pensions, and Retirement in Sweden," pp. 360-361.
} 
The Swedish public pension system enjoyed widespread popularity. By the 1980s, however, several problems with the system were becoming evident, including increasing funding deficits in both the universal and earnings-related (ATP) pension tiers, a low (and price-indexed) benefit ceiling in the earnings-related pension that was gradually compressing benefits as real earnings rose, and a benefit structure that disproportionately benefited workers with rising earnings profiles and relatively short work histories because it was based on the best fifteen years of earnings. ${ }^{4}$ Critics of the Swedish welfare state, notably the Swedish Employer's Federation, also criticized the pension system as part of an overall welfare state that harmed Swedish competitiveness through very high payroll taxes, ${ }^{5}$ lowered national savings, and reduced work incentives, especially for older workers. ${ }^{6}$

\section{THE NEW SWEDISH PENSION SYSTEM}

The new Swedish pension system is intended to achieve a number of goals simultaneously: a permanent stabilization of the pension payroll tax contribution rate, a tighter linkage between contributions and benefits in the social insurance component of pensions, improved incentives to work longer, and a separation of social insurance and income maintenance functions of the pension system. It makes a number of fundamental changes in pensions. ${ }^{7}$ The old flat-rate basic pension, which was mostly payroll tax financed but had very

\footnotetext{
${ }^{4}$ See Karen M. Anderson, The Welfare State in the Global Economy, and Palmer, "Swedish Pension Reform," p. 186.

5 The total employer social insurance contribution rate had reached $31.95 \%$ by 1990 . Sweden, National Social Insurance Board, Social Insurance Expenditure in Sweden 1999-2002, Stockholm: National Social Insurance Board, 2002, p. 28. ${ }^{6}$ Svenska Arbetsgivareföreningen, Marknad och mångfald-SAFs program för 90-talet [Markets and multiplicity - SAF's program for the 1990s]. Stockholm: Svenska Arbetsgivareföreningen, 1991.

${ }^{7}$ For overviews of the new pension system in English, see Sweden, Ministry of Health and Social Affairs, The Pension Reform-Final Report, June 1998, Stockholm: The Ministry, 1998, Edward Palmer, "Swedish
} 
little linkage between contributions and benefits, was abolished and merged with the earningsrelated ATP pension to form a new "income pension" based on notional defined contribution (NDC) principles. The link between pension contributions and benefits is tightened considerably, counting all contributions made over the course of an individual's working life, including contributions made by the Swedish state on an individual's behalf during periods of military service, child rearing, and education, as well as time spent in disability and receiving unemployment and sickness benefits. ${ }^{8}$ The monthly benefit is calculated based on (genderneutral) life expectancy at the time that the person begins receiving benefits, giving workers an incentive to work longer in order to receive higher pension benefits.

Redistribution across cohorts and across individuals within cohorts is also supposed to be ended in the income pension system, with each age cohort receiving a total payout from the income pension equal to its contributions plus a return on those contributions tied to economic growth. Each individual within a specific cohort will receive a share of the total "pie" available to their cohort equivalent to their share of total contributions for the cohort. ${ }^{9}$ Individuals can begin receiving retirement benefits at any age beginning at 61 , with no upper limit. ${ }^{10}$ The income

Pension Reform: How Did It Evolve, And What Does It Mean for the Future?," pp. 171-205 in Martin Feldstein and Horst Siebert, eds., Social Security Pension Reform in Europe, Chicago and London: University of Chicago Press, 2002, and Annika Sundén, How Will Sweden's New Pension System Work?, Chestnut Hill, MA: Boston College Center for Retirement Research Issue Brief No. 3, March 2000. ${ }^{8}$ In the year 2002, 88 percent of all pension rights earned were from contributions based on employment income, while ten percent came as transfers from other social insurance funds (e.g., for unemployment) and 2 percent from government for disability pensioners, national service, students in higher education, and child-rearing. See The Swedish Pension System Annual Report 2003, Stockholm:

Riksförsäkringsverket (National Social Insurance Board), 2003, p. 32. For a discussion of how pensionable income is calculated for these groups, see Ministry of Health and Social Affairs, The Pension Reform: Final Report, pp. 5-6, 20-23.

${ }^{9}$ The credits earned by persons who die before they retire remain in the notional asset pool for that cohort.

${ }^{10}$ Moreover, they can begin by receiving 25, 50, 75 or 100 percent of their full pension entitle ment. The actuarial value of portions of the pension begun at different times are calculated separately, so taking all or part of a pension at an earlier age results in permanently lower benefits. Older workers can always 
pension is financed entirely by a fixed 16 percent payroll tax. It will be operated largely on a Pay-As-You-Go rather than a funded basis, avoiding the double payment problem encountered with trying to move to advanced funding. As in the current system, however, "buffer" funds will help to even out demographic peaks and valleys.

Sweden's new pension system also includes a new "guarantee pension" receivable at age 65 that provides minimum income support for workers with low lifetime earnings. The guarantee pension performs the redistributive functions carried out by the flat rate pension and pension supplement under the old Swedish pension system. It will be financed entirely by general government revenues and income-tested against other public pension income.

In addition to the income pension and guarantee pension, the new system contains what Swedes call a "p remium reserve" pension: of the total $18.5 \%$ in pension contributions, $2.5 \%$ will be placed in an individual investment account that will operate on a defined contribution basis. Individuals were promised a wide variety of fund choices. To lower administrative costs—and especially the administrative burden on employers—-tallying of premium pension contributions and fund choices are centrally administered by a new government agency, PPM, and deposits into pension funds are made only once a year, after complete wage records for a calendar year are available from the state tax authorities and the State Social Insurance Board. Of course, this also means that there is a long time between when contributions are earned and when they are credited to accounts— up to sixteen months. In the period prior to their availability for active investment choices by contributors, those contributions earn interest equal to the rate of return on government bonds.

increase their pension amount by working longer, even after they have begun to draw a pension. Thus their incentives to remain in work are strengthened. Palmer, "Swedish Pension Reform," p. 195. 
Social organizations, notably the blue-collar labor confederation, LO, can partner with fund companies in offering fund choices. Swedes can change their fund allocations as often as they want without charge, but the system is not designed to facilitate "day trading"-fund switches often take three to five days, with foreign-based funds frequently taking the longest time to change. ${ }^{11}$ When individuals decide to start drawing their premium pension, they are offered a choice between converting their PPM fund balances into a full annuity or what Swedes call "flexible annuitization"- - leaving their funds invested and drawing down a share of those funds based on their (gender neutral) life expectancy. Lump sum withdrawals of PPM funds are not permitted, and fund balances are not inheritable.

The new pension system's planners recognized that many workers might not make an active pension fund choice. They created a Seventh Swedish National Pension Fund [Sjunde APfonden] to offer a default fund, called the Premium Savings Fund (Premiesparfonden), for those who do not choose a fund or simply prefer to have government invest for them. The Seventh AP Fund also offers a Premium Choice Fund (Premievalfonden) for active choosers who want the combination of a state-linked fund and a more equities-heavy portfolio than the Premium Savings Fund, with somewhat higher administrative costs. A quasi-state default fund was accepted reluctantly by Sweden's non-social democratic parties, who wanted to limit the role of the state in the Premium Pension system (and in the economy generally). Special rules imposed on the default fund reflect these concerns : individuals cannot actively opt for the Premium Choice Fund, the Fund is not allowed to market itself to potential "customers", persons who opt out of the default fund are not allowed to opt back in, and the default fund's shares are not to be voted on any issues that companies bring to their shareholders.

\footnotetext{
${ }^{11}$ Rolf Eriksson, "Snabbare fondbyten för PPM-sparare" [Quicker fund changes for PPM-savers], Dagens Nyheter, May 14, 2004.
} 
Sweden's new pension system is designed to be transparent in that individuals receive an annual statement about the size of their projected pensions from both the income pension and individual account (premium pension) tiers, as well as the guarantee pension, where applicable. Predicted benefits are given under several different economic scenarios regarding retirement age and overall performance of the Swedish economy. ${ }^{12}$ Thus workers are provided with increased information about their future pensions that they can use in making retirement and savings decisions. However, they also face increased uncertainty because their pensions depend on economic and demographic developments over which they have no control.

The transition to the new system will take place over a sixteen year period. Workers born in 1937 and earlier will have their pension benefit determined entirely in the old ATP system, and those born in 1954 and later will be entirely in the new system. In the intermediate group, an increasing share of pension rights will be determined under the new system. ${ }^{13}$ Thus current and soon-to-be retirees are protected from cutbacks that will accompany the shift to the new income pension system. But all workers born after 1936 now contribute to the individual account system.

\section{SYSTEM ADMINISTRATION AND COSTS}

Premium pension account holders can obtain information about their accounts and make changes in their allocation of funds by telephone, using the PPM's website or by mail. Heavy

\footnotetext{
12 The statement currently offers projections based on three different retirement ages (61,65 and 70) and two different rates of growth in average income (no growth and 2 percent annual growth). For a sample statement, see Försäkringskassan and Premiepensionsmyndigheten "Pensionsförklaringar." A Swedish language version is available from the National Social Insurance Board at http://www.rfv.se/press/pm/2004/docs2004/pm03_04bil2.pdf, accessed June 30, 2004.

${ }^{13}$ For those born in 1953, 19/20 of pension benefits are in the new system, 18/20 for those born in 1952, down to $4 / 20$ for those born in 1938. Workers in this transitional generation were also guaranteed at least as high a pension as they would have received through pension rights accrued under the old system through 1994. Ministry of Health and Social Affairs, The Pension Reform: Final Report, pp. 11, 33-34.
} 
automation and a lower-than anticipated rate of fund switches (discussed below) mean that PPM has been able to work with only about 200 total employees. Centralized management, automation, bulk trading of fund switches, and once-a-year transfer of funds into accounts help to keep the costs of the Swedish individual account system low: PPM's costs are only about 60 kronor (seven dollars) per pension saver. In addition, account holders pay an annual fee to fund managers. Fund management companies must agree to pay a rebate to PPM of their usual fees, with funds that have larger shares of PPM account funds paying a larger rebate. ${ }^{14}$ In 2002, 0.3 percent was deducted from the accounts of premium pension account holders to pay the costs of PPM administration. This was lowered to 0.27 percent in 2004, and PPM's goal is to get its charges down to 0.1 percent within fifteen years. ${ }^{15}$ In addition to PPM administrative fees, individual fund managers charged an average of 0.44 percent in 2002. The National Social Insurance Board estimated that if 2002 charge levels remained stable over time, pensions would be 22 percent lower than they would be in a system of zero administrative and fund manager charges. ${ }^{16}$ However, charges should fall as the system matures: for a new entrant when the system is mature, total costs are predicted to be only 0.25 percent annually, lowering the value of PPM pensions a total of 9 percent over a system of zero charges. ${ }^{17}$

\section{FUND ENTR Y RESTRICTIONS AND COSTS}

Designing and implementing the premium pension individual account system was a complicated task, both technically and politically. Sweden deliberately chose a policy that would allow a very broad array of fund choices. Sweden allows entry by any fund that (1) meets

\footnotetext{
${ }^{14}$ A description of PPM's rebate agreement is available in Swedish on PPM's website. See "PPM:s rabattmodell," at http://www.ppm.nu/tpp/infodocument/1:1;221,218;:, accessed November 30, 2003.

${ }^{15}$ Eriksson, "Snabbare fondbyten för PPM-sparare."

${ }^{16}$ National Social Insurance Board, [Riksförsäkringsverket], The Swedish Pension System Annual Report 2002, Stockholm: National Social Insurance Board, 2002, p. 33.

${ }^{17}$ Ibid, p. 33.
} 
European Union directives on portfolio diversification, with special exemptions to allow Swedish equity funds to qualify, despite the heavy concentration of the Stockholm stock exchange in a few issues, notably Ericsson; (2) agrees to give fee rebates to Premium Pension Authority (PPM); and (3) agrees to allow contributors the right to change funds as often as they like without charges, although the actual trading is done in bulk by the Premium Pension Authority. ${ }^{18}$ However, the PPM sets a limit of 25 funds per fund company or 50 per related group of companies. ${ }^{19}$

In the absence of significant entry barriers for investment funds, savers face an overwhelming array of fund choices. In the first round of fund choice in the fall of 2000, which involved around 4 million potential fund choosers for contributions made over the period from 1995 through 1998, individuals had to choose from a staggering array of 465 fund s. In 2001, for the second round (primarily for new labor market entrants), the number of funds increased to 558, with a further increase to 625 in the third round in 2002 and 648 in 2003 . The 2004 fund catalogue listed 664 funds offered by 39 Swedish and 47 foreign fund managers.

In its catalogue of fund choices, the Premium Pension Authority divides the funds into several categories and sub-categories. In 2002, for example, the 625 fund choices included 45 Swedish equity funds, 259 regional and global equity funds, 51 country equity funds (e.g., Japan, U.K.), 72 funds focused on specific sectors such as technology and communications and pharmaceuticals, 54 "mixed" funds that combine equities and interest bearing-securities, 42 "generation" funds that offer differing mixes of equities and interest-bearing securities

\footnotetext{
${ }^{18}$ For a critical perspective on the Swedish system of charges for fund managers in the individual account system, see Estelle James, James Smalhout and Dmitry Vittas, "Administrative Costs and the Organization of Individual Account Systems: A Comparative Perspective," pp. 254-307 in Robert Holzmann and Joseph E. Stiglitz, eds., New Ideas About Old Age Security, Washington, D.C.: World Bank, 2001, at pp. 291-296.

${ }^{19}$ The original limits were lower but were raised when two Swedish fund providers combined their operations.
} 
depending on years to retirement, and 102 funds concentrated in interest-bearing securities (Table 1). Within these categories, funds offer a variety of special features, such as active versus index-based management, ethical investment criteria, and more or less aggressive growth strategies.

A critical set of issues in implementing the new premium pension is how to encourage those contributing to the system to make a choice or multiple choices among funds, and what to do with the contributions of those who did not. Given the staggering array of potential choices facing contributors, Sweden's Premium Pension Authority tries to make at least minimal information about fund choices available to potential contributors. In each round, it has published and sent to new entrants to the system a very detailed booklet on how to go about making fund choices, as well as a fund catalogue listing all funds (broken down into categories and subcategories), a very brief description of each fund, the fund's total capital, fund management charges, fund returns for each of the last five years as well as a total five year return (where applicable), and a measure of fund risk (variability in return over the past three years). ${ }^{20}$

\section{CHOICE AND NON CHOICE IN THE INITIAL ROUND}

Several recent studies suggest hypotheses about active choice of pension funds when a default option is available. Overall, the factors that are likely to influence whether individuals make an active choice can be divided into two groups, first, characteristics of individuals (e.g., familiarity with financial markets, length of time until retirement, gender) and second, characteristics of the choice situation (e.g., desirability of the default option, complexity and information costs associated with active choice, availability of information and "priming" to

${ }^{20}$ See, for example, Premium Pension Authority, Fondkatalog för din premiepension 2003, Stockholm: PPM, 2003. 
choose). Choi, et al suggest that most individuals are likely to stay with the default option when it is available. ${ }^{21}$ Tversky and Safir have argued more generally that more complex decisions are more likely to lead to a delay in making decisions and thus to the default. ${ }^{22}$ Madrian and Shea, analyzing choices in $401(\mathrm{k})$ plans in the United States, find that women are more likely than men to choose the default option. ${ }^{23}$

Data from the first five rounds of PPM choice facilitate an assessment of these hypotheses. It should be noted at the outset that interest in the first round of PPM choice in the fall of 2000 was unusually high, in part because the amounts of money were relatively large, since four years of accrued contributions (for 1995-1998) were to be placed. Moreover, a substantial media campaign was mounted not only by the government's new Premium Pension Authority (PPM), but also by many fund companies, calculating that once individuals had made their choices, they were likely to stick with them. Nevertheless, only about two-thirds of those eligible to choose a fund in the initial round in the fall of 2000 did so. ${ }^{24}$

Initial data released by PPM found that women were slightly more likely than men to make an active choice in 2000 . There was also somewhat less active choice among the youngest (18-22) and oldest (58-62) groups, who presumably felt the least stake in making an active fund choice - the former because of their long time until retirement and the latter because their total fund size will be small and not a substantial part of their retirement pension. Nevertheless, rates of active choice among these groups were close to 60 percent in the 2000 round.

\footnotetext{
${ }^{21}$ James J. Choi, David Labison, Birgitte C. Madrian and Andrew Metnick, "Defined Contribution Plans: Plan Rules, Participant Decisions, and the Path of Least Resistance, in James M. Poterba, ed., Tax Policy and the Economy, Cambridge: MIT Press, 2002.

${ }^{22}$ Amos Tversky and Eldar Shafir, "Choice Under Conflict: The Dynamics of Deferred Decisions," Psychological Science, vol. 3 (1992) pp. 358-361.

${ }^{23}$ Birgitte C. Madrian and Dennis F. Shea, "The Power of Suggestion: Inertia in 401(k) Participation and Savings Behavior," Quarterly Journal of Economics, vol. 116 (2001) pp. 1149-1187.

${ }^{24}$ See for example "Intresset svalnar för PPM-valet," [Interest Cools for PPM Choice] Dagens Nyheter, November 15, 2000.
} 
A recent study by Engström and Westerberg, matching Swedish government data with records from the initial round of PPM pension fund choice, provides a rich body of data to examine hypotheses about which sub-groups are more and less likely to make an active pension fund choice. Using a multiple logit regression analysis that allows the effects of different causal factors to be assessed independently, Engström and Westerberg find that a number of factors dramatically (odds ratio of more than 1.30) increased the odds that a group would make an active choice in the 2000 round relative to the "reference group" of single, Swedish-born men with education only up to the compulsory level. These factors include employment in the financial services sector and having substantial private pension savings (both related to prior experience in financial markets) and being married. Other factors increased the odds ratio for active choice less substantially (odds ratio between 1.10 and 1.29), including more advanced education, higher income, and female gender. Controlling for other factors that make active choice more likely (notably marriage, children and financial market experience), Engström and Westerberg find that being relatively young (18-32) also modestly increases active choice.

Two factors-proximity to retirement (age 58-62) and having been born in a non-Nordic country-decrease the odds ratio relative to the reference group by more than forty percent (odds below 0.60). The sharp drop-off in fund choice among those born in non-Nordic countries is very likely related to the fact that many PPM materials, including fund catalogues, were available only in Swedish. Upper middle age (53-57) and birth in a Nordic country other than Sweden lower the odds of active choice (odds ratio between 0.80 and 0.90 ) significantly. ${ }^{25}$

\section{THE DROPOFF IN ACTIVE CHOICE IN LATER ROUNDS}

\footnotetext{
${ }^{25}$ Stefan Engström and Anna Westerberg, "Which Individuals Make Active Investment Decisions in the New Swedish Pension System?," unpublished paper, September 16, 2003.
} 
In the initial 2000 round of PPM choice, 67 percent of those eligible made an active choice. Fund choice fell dramatically in the four following rounds held for recent labor market entrants. Only $17.6 \%$ of these workers made a fund choice in $2001,14.1$ percent in $2002,8.4$ percent in 2003, and 9.4 percent in 2004 .

There were several reasons for the drop-off in choice, relating both to the characteristics of workers and to the characteristics of the choice situation. First, participants in later rounds were mostly younger workers who had a very long time until retirement, which may have made a fund choice seem of limited salience. Second, the low earnings and contributions of these new labor market entrants — the average contribution for those in the 2001 round was only 1356 kronor (less than USD250) —also limited the perceived importance of fund choice. Third, new entrants after the first round may also have been overwhelmed by the staggering array of fund choices.

These factors alone or together are implausible as sufficient explanations of the dramatic drop-off in active choice, however. As noted above, almost 60 percent of the youngest (18-22) age group, who make up most of the 2001-2004 group of new entrants, made an active choice in the initial 2000 round. Moreover, the growth in the number of choices offered after the first round was not so great that we would expect it to lead to the dramatic decline in active choice after 2000 .

If the skewed age distribution of new labor market entrants, small stakes, and large number of choices made relatively modest independent contributions to the drop-off in active choice after 2000, the interaction of these factors with several additional factors that affected new entrants' choice situation almost certainly had a greater impact. A fourth factor that was particularly important was the absence of a "contagion effect" that was present in the initial 
round of fund choice, since it involved the vast majority of adults in Swedish society under the age of 65, and was widely discussed among families and friends. The much smaller cohorts entering in later years did not experience this effect.

Fifth, while the PPM mounted substantial outreach and media campaigns in each round, and tried to increase internet accessibility for making choices, the fund companies, recognizing both the small sums at stake and the very broad field of funds available, did not mount substantial campaigns in later rounds as they had in $2000 .{ }^{26}$ Table 2 makes very evident why fund managers were decreasingly likely to make major advertising investments for specific funds as active choice declined in later rounds. It shows that by the 2003 round, only 9 funds attracted more than 800 new savers; funds in this most successful group attracted an average of only 279 thousand kronor (about US\$30,000) per fund. Fewer than 50 new participants were attracted by 477 of the 647 funds available for active choice in the 2003 round, with the median fund attracting only 19 new savers and a total of only 7,101 kronor from all new participants. When added to the modest earnings of most new participants and the management fee concessions demanded by PPM, the incentives for a major marketing campaign by fund managersespecially for individual funds rather than the overall "family" of funds operated by a fund management company_-were very small indeed. The media also paid much less attention to pension fund choice in the rounds held after 2000. These trends are evident in Table 3, which shows results from PPM's post-choice survey of new system entrants in each of the first four rounds. There is a dramatic decline across the board in the number of information sources that

${ }^{26}$ See Erland Huledal, "Vi hjälper dig välja rätt pensfond" [We help you choose the right pension fund], Aftonbladet, May 14, 2001; Helena Utter, "Ungdomarna struntar I PPM-valet" [Young people don't care about PPM-choice], Aftonbladet, May 29, 2001, Carten Larson, "Ungdomarna ligger lågt," [Youth lies low] Dagens Nyheter, May 18, 2001, Kalle Nilsson, "PPM bör fortätta fondinformationen," Dagens Industri, March 31, 2001; Lars Mattsson, "Fondbolag dra sig ur PPM," Dagens Industri, May 30, 2001, Leif Aspelin, "PPM lockar unga väljare med humor" [PPM entices young choosers with humor], Svenska Dagbladet, March 20, 2002. 
are cited by survey respondents as having been used in making their decision on how to invest their premium pension funds, reflecting an overall decline in active choice. But the declines are particularly striking in the categories for friends and acquaintances, fund providers (banks, insurance companies, fund managers) and the media, reflecting the decline in media attention, fund promotion and informal "contagion" from the first round. In the 2003 post choice survey, respondents report extremely low levels of contacts initiated by fund providers. ${ }^{27}$

Sixth, the widespread publicity given to the negative returns experienced by most Premium Pension savers-especially those in many of the most popular fund choices — may have diluted enthusiasm for making an active choice. The first round of PPM choice took place near the peak of the run-up in global equities markets. Later rounds have occurred against a backdrop of losses by most PPM account-holders. Indeed, the modest rebound in active choice in 2004 followed a rebound in equities markets and fund returns in 2003. Financial returns on PPM accounts are discussed further below.

A final factor that may have contributed to the decline in active choice is the availability of the $7^{\text {th }}$ AP Fund's Premium Savings Fund as a default. It was widely perceived, at least initially, to be a safe as well as low-cost (0.2 percent administrative costs) alternative to privately managed funds. ${ }^{28}$ Indeed, because the Premium Savings Fund was widely known to be available as a default, many individuals may have made a deliberate decision not to make a fund choice

\footnotetext{
${ }^{27}$ In the 2003 round, respondents who cited a particular source of information were asked whether they had initiated the contact themselves or it had been initiated by someone else. Of 1,009 respondents, only 14 said that the information had come at the initiative of a bank, 5 of a fund company, and 10 of an insurance company. See CMA AB, Eftervalsundersöknning 2003 [Post-Choice Survey, 2003], p. 26. It should be noted that in all of the post choice surveys, especially those after 2000, the percentage of respondents who said that they made an active choice is significantly higher than the percentage who actually did so.

28 See for example Karin Svensson, "PPMs första år: 17 miljarder bortblåsta” [PPM's First Year: 17 Billion Vanished Into Thin Air], Dagens Industri, October 6, 2001; and Karin Svensson, "PPM-basen tar raset med ett leende" [PPM Boss Takes Slide with a Smile], Dagens Industri, October 6, 2001.
} 
because the Seventh AP fund was their first preference, which they knew that they would get by doing nothing. Certainly the Fund's slogan that “Anyone who isn't willing or able to choose will get at least as good a pension as others-that's what we're here for," seemed to make the fund choice appear less than critical. Criticisms by Sweden's Social Democratic Commerce Minister, Leif Pagrotsky, that, given the high charges by Swedish fund managers, most Swedes would be better off having an ape invest their funds, may also have made the Seventh AP-fund seem like a good choice. ${ }^{29}$ Moreover, as will be discussed further below, the default fund has outperformed the weighted average of actively-placed funds in recent years, which may further have increased the attraction of non-choice.

Some leverage on the question of whether the $7^{\text {th }}$ AP' fund's Premium Savings Fund was a "deliberate passive choice" can be gained from PPM's post-choice surveys held after each round. A substantial percentage of survey respondents-19.4\% in $2000,37.1 \%$ in $2001,24.8 \%$ in 2002, and $15.7 \%$ in 2003 - said that they had not filled in their choice forms because they wanted the $7^{\text {th }}$ AP Fund to be their fund manager. ${ }^{30}$ When persons saying that they want the $7^{\text {th }}$ AP Fund to be their fund manager were asked why that is so, however, the results (shown in Figure 1) are a rather confusing mixture. A substantial percentage in each year cite perceived safety and security concerns (especially in 2001), but very few cite other positive qualities of the Premium Choice Fund or (except for the initial 2000 round) a preference for the state over a private company as a fund manager. A far greater aggregate number of respondents cite factors that have little to do with the $7^{\text {th }}$ AP Fund per se, such as not having enough information,

\footnotetext{
${ }^{29}$ Nicholas George, "Swedes Face Big Decision on Pensions," Financial Times, August 16, 2000, p. 21. Pagrotsky's thesis was tested by the tabloid newspaper Aftonbladet, which used a lemur from Stockholm's Skansen zoo to do the stock-picking, and found that it did indeed beat funds with high management fees. See Erland Huledal, "Ap-fonden slår de dyra fondbolagen" [Ape fund beats the expensive fund companies], Aftonbladet, November 11, 2000, p. 10

${ }^{30}$ CMA AB, Eftervalsundersöknning 2003 [Post-Choice Survey, 2003], pp. 9,34.
} 
wanting to be spared making a choice right now, or not having the energy or wanting to choose. These reasons are in the aggregate similar to those given by survey respondents who say that they did not make an active choice of funds rather than actively preferring the $7^{\text {th }}$ AP Fund (Figure 2).

\section{PATTERNS OF CHOICE AND RISK AMONG ACTIVE CHOOSERS}

The timing of implementation of the new Premium Pension system was unfortunate, since an accumulated four years of contributions (for calendar years 1995 through 1999) were poured into the market in late 2000, in the middle of an extraordinary nose-dive in world-wide equities markets in general and the Stockholm börs in particular. The $7^{\text {th }}$ AP Fund's Premium Savings Fund (the default fund) lost 10.6 percent of its value in calendar year 2001, while the other funds available for active choice lost a capital-weighted average of the same amount. The results for 2002 were even worse? a decline of 26.7 percent for the default fund and a capital weighted average of -33.1 percent return for active choice funds. An upswing in equity markets led to much more positive results in 2003: a positive 18.7 percent return for the default fund and weighted average of 16.2 percent for actively chosen funds. ${ }^{31}$

An analysis of premium pension investments through the end of September 2001 conducted by the Swedish business newspaper Dagens Industri found that almost all investors lost money, and many lost more than one-quarter of their contributions. ${ }^{32}$ The twenty most chosen funds in 2000 lost an average of 31 percent of their value from the beginning of the PPM's operation through late September 2001 — a fact that received considerable media

\footnotetext{
${ }^{31}$ The Seventh AP Fund's superior performance has been aided by its policy of hedging fifty percent of its foreign equity portfolio against the risk of fluctuations in currency value. This has helped to protect the fund against the declining value of the U.S. dollar. See Seventh Swedish National Pension Fund, Annual Report 2002, Part 2, p. 6 and Annual Report 2003, Part 2, pp. 5-6.

${ }^{32}$ Svensson, "PPMs första år."
} 
attention. ${ }^{33}$ By the end of 2002, fewer than one percent of pension savers had a positive return on their accounts, while more than three-quarters of pension savers had lost more than 30 percent of their contributions. A recovery in equities markets in 2003 improved those figures significantly, however: by the end of 2003, 12.7 percent of PPM account holders had a positive return on their contributions (many of them recent labor market entrants who had not experienced the initial downturn in equity markets), and just over 8 percent had lost more than 30 percent of their investments (Figure 3). ${ }^{34}$

These sobering trends in fund value provide the context within which we can examine the patterns of choice and risk among PPM depositors. What criteria did they apply in making fund choices? Were some groups more risk-averse than others? Did contributors change behavior over time, either in terms of fund switches or the types of fund choices made by new contributors? Are there signs of either excessive risk taking or excessive trading among some groups?

In the initial round of choices in the fall of 2000, those people who did choose chose an average of 3.4 funds, so most did diversify. But that number fell to 2.8 funds per new entrant in the 2001 round. ${ }^{35}$ Data from PPM's annual post-choice survey of new entrants also provides some insights into the considerations that active fund choosers used in making their choices among funds, although comparison across years is made more difficult by a change in the range of options used in the survey over time. The fact that a much higher rate of survey participants claimed to have made an active choice in later rounds than actually did so also casts some doubt on the credibility of the survey results. Nevertheless, the survey findings shown in Table 4 are

${ }^{33}$ Elisabeth Lindham, "Favorit in PPM föll med 60 procent" [PPM Favorite Falls 60 Percent], Aftonbladet, September 21, 2001, "PPM-fonden Contura vanligt med dåligt val" [PPM fund Contura a Common But Bad Choice], Dagens Industri, September 21, 2001.

${ }^{34}$ PPM, “Årstatistik 2002,http://www.ppm.nu/tppinfodocument/1:1;200013;:, accessed December 8, 2003., and PPM, "Facta om premiepension, accessed December 8, 2003.

${ }^{35}$ Lars Matttsson, "Fondbolag hotar dra sig ur PPM" ["Fund company threatens to withdraw from PPM, Dagens Industri, May 30, 2001]. 
useful. They consistently suggest that many active choosers chose multiple fund managers and/or types of funds in order to spread risks. They also suggest that both high recent returns and low fund charges played an important role in fund choice. The role attributed to opinions given by experts declined substantially after the initial round-probably reflecting a decline in media interest and coverage in later rounds. Not surprisingly, given the young age of most new entrants in later rounds, recommendations from family members were important in both the 2003 and 2004 rounds (this option was not included in the first two surveys). Choosing among funds offered by financial institutions with which the entrant already had a relationship dropped off substantially after the initial round - again not surprising given the young age of most labor market entrants.

Given the poor performance of equity funds since the inception of the Swedish individual account system, it should not be surprising that there was a shift away from equity among active choosers in the 2003 round, after three initial rounds in which almost three quarters of activelyplaced funds were put in equity funds. The percent of actively chosen funds that were placed in fixed-income funds rose from two percent in the initial round in 2000 to eight percent in 2001 and 26 percent in 2003, although a majority of contributions are still placed in equity funds (Table 5). However, these trends among active users have been overwhelmed in their effects by the shift away from active choice toward passive investment in the equities-heavy Seventh AP default fund, which essentially functions as a global equities fund.

A potentially more serious problem is that a small minority of active choosers appears to be over-concentrated in high-risk funds with high recent returns, despite the high risk generally associated with such investments. Choosers in the initial 2000 round invested heavily in tech funds, since those showed the highest rates of return in the Fund Catalogues they received from 
the Premium Pension Authority (PPM). By far the most commonly chosen fund overall in the initial round was the high-tech Roburs Aktiefond Contura, which was listed in PPM's 2000 fund catalogue as having had a 534.2 percent return over the past five years after fund charges. ${ }^{36}$ Contributors who chose the fund placed an average of 25.3 percent of their contributions in that fund. But the Roburs Contura fund suffered the fate of most tech-heavy funds, losing 32 percent of its value in 2001. ${ }^{37}$ Similar patterns are evident in more recent rounds. In the 2002 round, for example, two of the five most frequently chosen funds were Russian equity funds, reflecting very high returns reported for those funds in PPM's fund catalogue. ${ }^{38}$ Here the concentration of funds was even more alarming with contributors placing an average of 44 and 38 percent of their contributions in those funds (Table 6). Russian equity funds were also the two most frequently chosen funds in the 2004 round (Table 6).

One potential risk that does not seem to have materialized, however, is excessive trading by account holders who are attempting to make gains through market timing or who panic in response to short-term market fluctuations. In fact, an April 2001 poll found that 41 percent of participants who made an active fund choice in the initial 2000 round of PPM choice had completely forgotten which funds they had chosen, while 32 percent could remember some of their fund choices. ${ }^{39}$

Surprisingly little fund-switching has occurred since the inception of the PPM system. The system was initially designed to have a capacity of fifteen to twenty thousand fund switches

\footnotetext{
${ }^{36}$ PPM, Fondkatalogen 2000 [Fund Catalogue 2000], p. 42.

${ }^{37}$ Fondkatalog för din Premiepension 2002, p. 48.

38 "Unga struntar i pensionsval" [Young don't care about pension choice], Svenska Dagbladet, April 17, 2002; "Unga satsa på Rysslandsfonder" [Young gamble on Russia funds] Aftonbladet, April 9, 2002. ${ }^{39}$ Martin Hammarström, "Svenskarana förtränger PP-valet" ["Swedes repress PPM choice"] Dagens Industri, April 19, 2001. See alsoKristina Kamp, "PPM stänger i Ljusdal" ["PPM closes in Ljusdal"], Dagens Nyheter, May 17, 2001; Lars Matttsson, "Fondbolag hotar dra sig ur PPM" ["Fund company threatens to withdraw from PPM, Dagens Industri, May 30, 2001].
} 
per day, but there initially were only about two thousand per week, leading to the reduction of telephone service personnel and the closing of one telephone service center. ${ }^{40}$ In 2001 , there were only 133,000 fund switches among the roughly 5 million PPM account holders. That number grew to 232,360 fund switches in 2002, of which 83 percent were made via PPM's website. The number of fund switches increased to 358,577 in 2003, with 88 percent made on- line. ${ }^{41}$ While the year-to-year figures suggest strong growth in fund switches, month-by-month data (Figure 4) suggest that many of the increases were the result of unusually high levels of fund switching in the first half of 2002 and October and November of 2003. In any case, the number of annual fund switchers remains very modest relative to the depositor base. Unfortunately, individual-level fund switching data, which would allow us to determine whether fund-switching is concentrated among a much smaller number of contributors making multiple switches, is not available.

\section{THE DEFAULT FUND}

The Seventh AP Fund has stated its objective as "People who do not have a fund manager, for whatever reason, should receive the same pension as others-that is our goal." But what does this goal mean in practice? Should a default fund aim to preserve the funds that have been invested, minimizing risk, as most default funds in the United States do? Or should it seek growth with reasonable attitude toward risk? Or mirror investment strategies of those who do choose? Or choose the optimal strategy for the median-age customer? Or change the investment mix for specific cohorts of workers as their retirement age nears?

The experience of the Seventh AP Fund clearly shows that there is likely to be a tension

\footnotetext{
${ }^{40}$ Karin Svensson, "Spararna svikar PPM" ["Depositors jilt PPM"], Dagens Industri, March 29, 2001.

${ }^{41}$ PPM, “Årstatistik 2002,’http:://www.ppm.nu/tpp/infodocument/1:1;200013;:, accessed December 8, 2003, and “Årstatistik,"http:://www.ppm.nu/tpp/infodocument/1:1;200670;:, accessed June 24, 2004.
} 
in any default fund between the objective of preserving capital and that of "having as good a pension as others," which over the long term requires substantial investments in higher yielding equity investments. To achieve the latter objective, The Seventh Pension AP Fund set an investment time horizon of 25 years for its Premium Saving Fund, and an initial portfolio allocation of 65 percent foreign equities, 20 percent Swedish equities, and 14 percent Kingdom of Sweden inflation linked bonds. This initial portfolio was later changed to 90 percent in

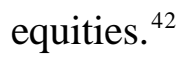

The Swedish experience with the premium pension also suggests that a default fund may also become involved in debates over domestic, ethical and environmental investment practices. Indeed, the $7^{\text {th }}$ AP Fund took an even more aggressive stand on these issues than the other state pension funds, in part because it is not allowed to vote its shares. It instead decided to disinvest in companies that had been found guilty by impartial tribunals of violating international conventions to which Sweden had adhered, including conventions on human rights, child labor, various ILO conventions, international environmental conventions, and conventions against bribery and corruption. On the basis of these criteria, AP7 decided in 2001 to sell its shares in 27 companies, including such well-known multi-national companies as Coca-Cola, General Motors, ITT, Nestlé, Sears, Texaco and WarMart, as well as one Swedish company, Esselte. But the fund continued to invest in companies with interests in tobacco, gambling, alcohol and weapons production—indeed its managing director argued that since the Swedish state had interests in those same sectors, following such a rule consistently would mean that it would have to get rid of

${ }^{42}$ In the fund reallocation, five percent of funds were reallocated from Swedish indexed bonds to Swedish equities. The Premium Choice Fund featured an even heavier 97 percent investment in equities. See Seventh Swedish National Pension Fund, Sjunde AP-fonden. År 2001, Stockholm: The Fund, 2002. 
Swedish government bonds. ${ }^{43}$

\section{CHALLENGES FOR THE SWEDISH INDIVIDUAL ACCOUNT SYSTEM}

The most important challenge for the Swedish premium pension system is how to engage new labor market entrants in the premium pension process at an early point. One can argue that these workers are being rational in "choosing" the default fund in overwhelming numbers, since it has outperformed the weighted index of actively chosen PPM funds. But failure to engage young workers undercuts the legitimacy of the new pension system. It also raises concerns among non-socialists about the huge size of the state-affiliated default fund as those workers increase their earnings. Engaging young workers is likely to remain very difficult, however, so long as private fund managers limit their marketing activities, the vast majority of account holders suffer losses, and the default fund continues to outperform the fund index as a whole. And so long as the PPM is required to pass on the costs of engagement activities to current depositors in the form of higher management fees, there will be strong incentives to limit those efforts. Indeed, the PPM has in recent rounds scaled back its public information campaigns to engage new workers, and its has called for additional government help in educating future contributors-for example by including consumer finance education in school curricula. ${ }^{44}$

Another challenge for Sweden is maintaining a political coalition in favor of the relatively non-restrictive investment practices carried out by managers of the state AP pension

\footnotetext{
${ }^{43}$ Investment in those companies was to be barred for five years, although the Fund's board could restore them earlier if there was evidence that they had come into compliance with the relevant conventions. See Seventh Swedish National Pension Fund, Sjunde AP-fonden. Ar 2001, p. 2, and "Coca-Cola och Nestlé åkte ut när AP-fond följde etikregler [Coca-Cola and Nestlé went out when AP fund followed ethics rules," Svenska Dagbladet, February 22, 2002.

${ }^{44}$ See for example Lars Matttsson, "Fondbolag hotar dra sig ur PPM" ["Fund company threatens to withdraw from PPM, Dagens Industri, May 30, 2001, and "PPM söker regeringshjälp" ["PPM seeks government's help"] Dagens Nyheter, April 2, 2003.
} 
funds? both the $7^{\text {th }}$ AP fund acting as a default option in the premium pension and the First to Fourth AP Funds as buffer funds for the income pension. Leaders within the Social Democratic party have criticized the AP Funds' investment practices as undermining Swedish industry in their single-minded pursuit of high short-term returns. Even Prime Minister Göran Persson has lamented current investment rules, arguing that a pensioner depends not only on "the yield in state pension funds, but also that Sweden has a functioning industry that pays taxes in Sweden. That is the crucial security for me as a pensioner." 45 The head of the Seventh AP-Fund, which administers the default fund for non-choosers, has vigorously defended current investment practices as necessary to protect the value of future pensions. ${ }^{46}$ Rules on ethical and environmental criteria for investments are also likely to remain contentious.

\section{LESSONS FOR THE UNITED STATES}

Sweden offers a number of lessons about the issues that need to be anticipated in designing and implementing an individual account scheme that would be relevant if the United States moves in that direction. These lessons can be divided into several categories: the advantages and limitations of central administrative organizations, entry barriers, limiting risk, engaging workers in fund choice, continuing communication obligations, and design of a default fund. ${ }^{47}$

\section{Centralized Administration}

\footnotetext{
${ }^{45}$ Karin Svensson, "Göran Persson vill ha blå-gula AP-fonder" [Göran Persson Wants to Have Blue and Yellow State Pension Funds], Dagens Industri, September 19, 2001; “'AP-fonderna ett hot mot svensk industri'” ['AP Funds a Menace to Swedish Industry], Dagens Industri, September 8, 2001.

${ }^{46}$ Kjell-Olof Feldt and Peter Norman, "Försämra inte pensionerna, Persson" ["Don't make pensions worse, Persson"], Dagens Nyheter, October 16, 2001. Feldt is a former Social Democratic finance minister, now chairman of the Pensionsforum, a pension research group. Norman is managing director of the $7^{\text {th }}$ AP fund.

47 Another potential set of lessons relates to annuitization requirements, survivor benefits, inheritability of fund assets and other aspects of fund payout, but these are beyond the scope of the present paper.
} 
The Swedish model offers a number of lessons concerning the advantages and disadvantages of having a strong state agency role in administration of assets. Some of the advantages and disadvantages of this approach are clear. On the plus side, centralized administration minimizes the additional paperwork burden for employers, who can follow existing procedures for submitting payroll taxes and do not need to get involved in administering fund choices and payments to multiple funds by their employees. Thus it almost certainly weakens opposition from employers-especially small employers-to adoption of a system of mandatory retirement savings accounts. Central administration of funds also makes it easier to permit very wide fund choice and to negotiate reductions in management fees by fund providers. On the negative side, use of the tax system to collect funds also contributes to a very long lag time in crediting of individual pension accounts. In Sweden, moreover, integration of the system with payroll tax records on an annual basis has also meant that these investments are placed into the market in very large annual lumps that could potentially disrupt bond and foreign exchange markets. ${ }^{48}$ This would be even more problematic in placing the enormous sums that would be involved with contributions from a country the size of the United States.

There are also issues of generational equity for the first generation of contributors to a centralized system. When government chooses to pass on the costs of the centralized management agency (PPM) and default fund to contributors, as has been done in Sweden, rather than paying them out of the general budget, the fixed costs of establishing and operating such a system are borne disproportionately by the initial contributors, because the system has a relatively small number of contributors and small asset base of contributions. In Sweden, the government made loans to both PPM and the Seventh AP Fund to cover these costs, which are

\footnotetext{
${ }^{48}$ See for example Fredrik Braconier, "PPM-flöde sänkte krona" ["PPM torrent sank the krona"], Svenska Dagbladet, January 27, 2004.
} 
being repaid over a long period. Nevertheless, the management costs per krona of contribution assets are much higher in the initial period. In addition, the high costs of engaging new entrants after the initial round are, under the current Swedish system, unfairly borne by current depositors in the form of higher PPM operating expenses.

U.S. policymakers, operating in a very different political environment, might want to consider a different model if a centralized management agency were to be established here. First, it would be politically more acceptable in the United States to pay all of the capital and operating costs (including advertising costs to engage new participants) of a central "clearinghouse" agency out of the general government budget rather than as a charge on contributions. Second, given what has turned out to be the relatively limited within-year level of fund changing activity in Sweden, as well as the close integration of account management and reporting functions with the roles performed by the Social Security Administration in the United States, it might make more sense to keep management of individual accounts within SSA, under the jurisdiction of a new bureau established for that purpose, rather than creating a new separate agency as has been done in Sweden with the PPM. The main risk of such an approach is that it could lead to pressure on local SSA offices to deliver services that they are not set up to deliver (e.g., helping people make fund changes at a time of financial panic) as well as services that it would be inappropriate for them to provide at all (advice on choice of individual funds). If account management were retained within SSA, very clear messages would have to be conveyed to the public that fund-switching services were only available through other mechanisms (e.g., mail, phone and internet) and that no advice on choice of individual funds can be provided by SSA. This would require a major-and ongoing — campaign of public information. But some misunderstanding is almost inevitable, and it could be damaging to the agency's image and 
morale. If, on the other hand, a new separate agency was established as a clearinghouse for individual accounts, it would be essential to maintain close cooperation and compatibility of data systems between that agency and SSA.

Swedish experience also suggests that it takes a long lead time to get a new central administrative organization up and running. The information technology requirements for such a system are especially daunting. Indeed, Sweden's scheme had to be delayed in order to make sure that the technology would work, and the PPM ended up having to pay more than $\$ 25$ million dollars for a computer system that it never used after cancelling a contract with the system's vendor. ${ }^{49}$ The propensity of Congress to demand immediate action once they have decided on an action is a well-documented feature of American policymaking, ${ }^{50}$ and one that could have very negative consequences both in the short term and in the long term (by undermining public confidence in the system and the willingness of fund managers to participate) if it caused serious implementation problems in a new individual account program.

\section{Entry Barriers for Fund Providers}

Swedish experience suggests that it is possible to get a large number of fund providers to participate in a state administered individual account system even when substantial rebates are required. Indeed, the Swedish experience suggests that the number of choices in an individual account system can be very high—and grow over time-unless gatekeepers impose meaningful entry barriers. The number of choices in the Swedish system is almost certainly so high that it discourages active choice by overwhelming potential advisors who, especially in later rounds, are mostly young, unsophisticated in investing, and do not perceive a strong interest in fund

\footnotetext{
${ }^{49}$ Peter Carlberg, "Värdelöst datasystem kostade PPM 170 miljoner" ["Worthless datasystem cost PPM 170 million"], Svenska Dagbladet, May 18, 2004.

${ }^{50}$ See for example Martha Derthick, Agency Under Stress, Washington, D.C.: The Brookings Institution, 1989.
} 
choices. Rather than the Swedish system of relatively open entry by individual funds, it might make more sense in the United States to offer a much smaller range of "generic" funds—perhaps ten to twenty — that offer investors a range of choices in terms of equities versus fixed return investments, domestic versus international exposure, etc. In order to prevent the size of individual pools of capital, each fund option could be contracted out to multiple fund managers, with recipients receiving a rate of return that was the weighted average across all of those fund pools. Of course, moving away from having the government pension authority acting primarily as certifier of fund options to picking fund managers does raise difficult issues for the body doing the picking, since the fees generated for fund providers will presumably be very large. The federal government's Thrift Savings Plan has managed these issues with little controversy, but the stakes in a society-wide individual account scheme will of course be much greater.

\section{Limiting Risk}

In addition to limiting the number of funds that savers in an individual account system can choose, Swedish experience suggests that some constraints on the content of fund options may be appropriate in an individual account system. The ten worst performing funds in the first year of the Swedish premium pension—all stock funds with a technology focus—-lost a staggering average of 76.6 percent of their value. ${ }^{51}$ While most investors probably did not put all their funds into such funds, there were no legal constraints on doing so. Similar issues arise with regional equity funds in the Swedish system, notably funds focused on Eastern Europe. The U.S. economy is diverse enough, and U.S. equity markets are sufficiently developed and transparent to make a U.S.-only diversified equity fund a reasonable retirement savings vehicle. But this is not true of many developing markets. Even in a system that permits a broad range of funds, policymakers may want to consider restrictions on overly specialized funds. Limitations on

${ }^{51}$ Svensson, "PPMs första år." 
sector-specific as well as country- and region-specific funds are particularly important if fund choices are limited to a relatively narrow range of options.

\section{Engaging Workers in Fund Choice}

A fourth set of lessons for the United States that is clearly highlighted by the Swedish experience with individual accounts concerns the need to think through how to engage new workers in choosing a fund. The 2.5 percent of earnings contributed by Swedish workers translates into relatively small absolute amounts for young workers, who may not perceive themselves as having a real stake in making a choice. The sums being debated in most U.S. proposals for Social Security reform are of similar magnitude. Neither strong media efforts by the Premium Pension Authority nor efforts to make choice as easy as possible have yet overcome barriers to participation in Sweden, especially after the first round of choice when media attention was highest and virtually the whole labor force faced the need to make a choice simultaneously. Similar problems would likely surface in the United States, where a population thirty times greater than in Sweden would seem likely to increase fund managers' willingness to spend money to market their plans-were it not for the fact that marketing costs in the much larger U.S. market are also dramatically higher than in Sweden.

Swedish evidence from the Engström and Westerberg study also suggests that there is likely to be a substantial gap in active choice between native English speakers and those with another first language. Promoting active choice in the United States would likely require government efforts to provide materials in languages other than English. Fund managers might not see advantages in providing these materials themselves, especially if low entry barriers meant that there were a large number of funds competing in relatively small (and frequently lowincome) niches. 


\section{Continuing Communications Obligation}

Use of a centrally-administered system of individual accounts carries with it a continuing moral, if not legal, obligation on the part of the administering agency to keep account holders informed of important developments in the specific funds they have chosen after they have made their fund selections. This is particular true when (as in the Swedish case) individual fund managers do not know which individuals in the mandatory individual account system hold their funds, and they do not have a mechanism to communicate directly with fund shareholders.

The Swedish experience suggests that two situations in particular are likely to require communication with those holding specific funds. One is when fund managers raise administrative fees for specific funds. In 2004, for example, Skandinaviska Enskilda Banken increased fees on its money-losing PPM generation funds from 0.5 to 1.2 percent. The 71,000 fund holders received an initial letter from PPM that informed them that fees were being raised and a follow-up letter with more details. But critics have charged that in a system in which most account holders do not pay close attention to their accounts after making their initial selection, there is a significant temptation for fund managers to raise fees after an initial round that enrols all current labor market participants in order to boost profits. ${ }^{52}$

A second situation in which ongoing communications capacity with account holders is important is when a fund manager decides, for whatever reason, to wind up a fund or withdraw it from the state system. This has happened only a few times in the PPM system. Account holders are notified by PPM and told how to move their funds to another fund. If they do not do so, their funds are moved to the 7th AP Fund's default fund.

52 "SEB chockhöjeravgifter för PPM-fonder," [“SEB boosts charges for PPM Funds"] Dagens Nyheter, January 30, 2004. 
As these cases suggest, a continuing capacity for the administering agency to communicate with account holders in a timely fashion is essential to the effective operation of a centrally administered fund. Also essential, however, are policies to govern when that communication takes places and what information is provided. Certainly wind-up of a fund should require notification and an opportunity for an account-holder to make a major new fund choice. So too should a major increase in fund charges. But what about a minor increase in fees? Or a decrease in management fees? Or a shift in a fund's management team? Providing a lot of information on a frequent basis would clearly raise central administrative costs significantly. But providing information only when there are major increases in fund charges would likely lead to criticisms by account holders and advocacy groups. Clearly individual fund holders will have to bear a major part of the responsibility for monitoring funds in a centrallyadministered system of individual accounts. It is also clear, however, that the administering agency will need to have clear and comprehensive policies on when and why it communicates with holders of specific funds.

\section{A Default Fund}

The Swedish experience clearly suggests the importance of a default fund for nonchoosers in any centrally-administered system of mandatory individual accounts. Swedish "abstainers" (soffliggare, literally those who lie on a sofa) are put into a fund operated by the Seventh Swedish State Pension Fund. Policymakers in the United States might want to handle who administers a default fund differently than in Sweden, however. Establishing a new government- affiliated management entity for the default fund would be both costly and politically controversial. Contracting out management of a default fund to several different fund 
management firms by competitive bidding would likely spark less opposition.

At least as important as who administers the default fund is the question of how the default option is designed. The experience of the Swedish Seventh Pension Fund's Premium Savings Fund shows that there are very real trade-offs between long-term growth and protection of investment capital for those who, for whatever reason, abstain from making a fund choice. The Premium Savings Fund has a long time horizon—its target investor is a 42 year old — so it invests 95 percent in equities and the rest in Swedish government indexed bonds. Accounts in the Premium Savings Fund suffered serious losses in both of its first two years of operation.

There is no obvious "correct" answer to the growth-versus-security trade-off, but it is probably best to offer different defaults for younger and older workers, and to progressively move the funds of older "abstaining" workers into more secure investments. Indeed, the Swedish Seventh State Pension Fund, which operates the default option for Swedish "abstainers," is now considering creation of "generation funds" that will have different portfolios for different age groups of abstainers. Implementing such a system will require further approvals from the Swedish government, however. ${ }^{53}$ U.S. policymakers might also want to consider completely different alternatives, such as placing abstainers' contributions in a pool of funds that represents the average of all choices for persons in their age group.

If a government-operated default fund were to be set up as part of an individual account tier in the United States, Swedish experience also suggests that it would not be free of controversies over environmental, ethical and domestic investment criteria. Of course, such criteria would not necessarily be adopted in a political system that is much more conservative than Sweden's—or there might be pressures for a different set of criteria.

\footnotetext{
${ }^{53}$ Lars Mattson, "Soffligarna hamnar i generationsfonder" [Abstainers To End Up in Generation Funds], Dagens Industri, January 23, 2001.
} 


\section{CONCLUSIONS}

The issues outlined here are far from exhaustive. Many other issues would clearly have to be resolved in design of a centrally-managed system of individual retirement savings accounts. For example, how many different funds should individuals be allowed to choose? (Sweden currently allows five, but there have been discussions of allowing an increase to ten).

Care should also be taken in extrapolating from Swedish experience to other national contexts. Decisions on many design issues-e.g., whether to erect meaningful entry barriers for funds, and whether and how to impose diversification requirements? would have to be made in any system of mandatory individual accounts. But the behavioral responses by pension savers observed in Sweden might not be repeated exactly in the United States or other countries. Those responses reflect both characteristics of specific economies and societies and specific choices made in the design of a retirement income system. For example, if a larger share of pension contributions were directed into the individual account tier than in Sweden, it is possible that rates of active choice might be higher, and fewer persons might concentrate their contributions in high-risk investments. The Swedish evidence nevertheless suggests that both the design choices and administrative challenges associated with a centrally-managed system of individual retirement savings accounts are considerable. 
TABLE 1

SWEDEN PREMIUM PENSION FUND OPTIONS 2002 and 2003

\begin{tabular}{|l|c|c|}
\hline Fund Type & $\begin{array}{c}\text { Number of Funds, } \\
2002 \text { Round }\end{array}$ & $\begin{array}{c}\text { Number of Funds, } \\
\text { 2003 Round }\end{array}$ \\
\hline$\cdot$ Swedish equity funds & 45 & 56 \\
\hline$\bullet$ Regional/world equity funds & 259 & 259 \\
\hline$\bullet$ Country equity funds & 51 & 51 \\
\hline$\cdot$ Sector funds & 72 & 72 \\
\hline$\cdot$ Mixed funds & 54 & 56 \\
\hline$\bullet$ Generation funds & 42 & 39 \\
\hline$\cdot$ Interest-bearing funds & 102 & 107 \\
\hline Total & 625 & 648 \\
\hline
\end{tabular}

Source: See Premium Pension Authority, Fondkatalog för din premiepension 2002, Stockholm: PPM, 2002, and Premium Pension Authority, Fondkatalog för din premiepension 2003, Stockholm: PPM, 2003 
Table 2

DISTRIBUTION OF PENSION FUND OPTIONS BY NUMBER OF NEW CONTRIBUTORS IN 2003 CHOICE ROUND

\begin{tabular}{|l|l|c|}
\hline $\begin{array}{l}\text { New Contributors Within } \\
\text { Range Specified }\end{array}$ & $\begin{array}{l}\text { Number of Funds with New } \\
\text { Contributors in Range } \\
\text { Specified }\end{array}$ & $\begin{array}{l}\text { Average Amount of Total } \\
\text { Deposits by All New } \\
\text { Contributors For Funds in } \\
\text { Category (in Swedish Kronor) }\end{array}$ \\
\hline 137,589 (default fund) & 1 & $150,388,876$ \\
\hline 500 to 799 & 9 & 279,010 \\
\hline 400 to 499 & 7 & 228,358 \\
\hline 300 to 399 & 15 & 144,049 \\
\hline 200 to 299 & 10 & 105,225 \\
\hline 100 to 199 & 54 & 62,836 \\
\hline 50 to 99 & 75 & 29,132 \\
\hline 20 to 49 & 152 & 13,549 \\
\hline 10 to 19 & 115 & 6,351 \\
\hline Less than 10 & 210 & 1,941 \\
\hline
\end{tabular}

Source: Premium Pension Authority website. 
TABLE 3

INFORMATION SOURCES FOR NEW PPM SYSTEM ENTRANTS, 2001-2004

(percent of survey respondents saying they used information source)

\begin{tabular}{|l|c|c|c|c|}
\hline \multirow{2}{*}{ Information Source } & \multicolumn{4}{|c|}{ Year } \\
\cline { 2 - 5 } & 2000 & 2001 & 2002 & 2003 \\
\hline Family members & 39 & 39 & 38 & 43 \\
\hline Choice packet from PPM & 64 & 45 & 37 & 30 \\
\hline Mass media/Newspapers/TV & 53 & 25 & 13 & 10 \\
\hline Friends/acquaintances & 42 & 23 & 13 & 10 \\
\hline Bank & 30 & 12 & 5 & 6 \\
\hline PPM's website & 7 & 5 & 8 & 4 \\
\hline School & $*$ & $*$ & 3 & 4 \\
\hline Work colleagues & 2 & $*$ & 5 & 4 \\
\hline Insurance company & 23 & 8 & 2 & 2 \\
\hline Fund company & 20 & 7 & 2 & 1 \\
\hline Trade union & 21 & 4 & 2 & 1 \\
\hline Social insurance office & $*$ & 2 & 1 & 1 \\
\hline Other web sites & $*$ & 3 & 1 & 1 \\
\hline Immigrant language brochures & 0 & 0 & 0 & 0 \\
\hline Other & 2 & 6 & 2 & 0 \\
\hline Total & 303 & 179 & 132 & 117 \\
\hline No answer, don't know & 7 & 26 & 38 & 40 \\
\hline
\end{tabular}

Answer to the question asked of all survey respondents: "which of the following information sources have you used to help with how your premium pension should be invested?" Answers total more than 100 percent because more than one answer was possible. The "school" alternative answer was missing in 2000 and 2001, as was "social insurance office" and "other web sites" in 2000 and "work colleagues" in 2001. In 2000, "PPM's web site" was formulated as "Internet" and "work colleagues" as "work."

Source: CMA AB, Eftervalsundersökning 2003 [Post-Choice Survey, 2003], p. 25 available on PPM's web site at http://www.ppm.nu/dbfiles/pdf/1182.pdf, accessed December 1, 2003. 
TABLE 4. REASONS GIVEN FOR CHOOSING FUNDS, 2000-2003 ROUNDS

\begin{tabular}{|c|c|c|c|c|}
\hline & 2000 & 2001 & 2002 & 2003 \\
\hline Different administrators for different funds & 57 & 46 & N.A. & N.A. \\
\hline Several different fund types to spread risk & N.A. & N.A. & N.A. & 49 \\
\hline Several different fund managers & N.A. & N.A. & 47 & 46 \\
\hline Fund that family member recommended & N.A. & N.A. & 46 & 46 \\
\hline One or several foreign managers & N.A. & N.A. & 31 & 40 \\
\hline Funds that have the lowest charges & 46 & 25 & 30 & 39 \\
\hline Funds that have high/highest recent returns & 44 & 38 & 33 & 33 \\
\hline Among my bank's funds & 38 & 24 & 21 & 25 \\
\hline Administrator with world-wide experience & 36 & 31 & N.A. & N.A. \\
\hline A fund that friends/acquaintances recommended & N.A. & N.A. & 23 & 21 \\
\hline Funds given the highest marks by experts & 32 & 18 & 12 & 16 \\
\hline Among my insurance company's funds & 24 & 12 & 8 & 7 \\
\hline Same funds I already save in & 19 & 14 & 14 & 18 \\
\hline Funds recommended by, e.g., newspaper & 11 & 15 & 3 & 3 \\
\hline Other & 10 & 22 & 14 & 4 \\
\hline Uncertain, don't know & 1 & 9 & 5 & 4 \\
\hline Total & 318 & 254 & 287 & 351 \\
\hline
\end{tabular}

Question: "What did you think about when you made your choice? Which statement(s) are accurate for you?" Ask of persons who said that they made an active choice. Question wording varies slightly. Not all options were given in all rounds.

N.A.=Not asked in this round of pension choice.

Sources: Sifo Research and Consulting, Eftervalundersökning avseende premiepensionsvalet, 2000, 2001, and CMA AB, Eftervalsundersökning 2003, p. 35, and Eftervalsundersökning 2003, p. 31 
TABLE 5

FUNDS CHOSEN BY NEW PPM ENTRANTS, 2000-2003

(by amounts placed)

2000

2001

2002

2003

As Percent of Actively Placed Funds

Equity Funds, Total
Swedish equity funds
Regional/world equity funds
Country equity funds
Sectoral equity funds
Mixed funds
Generation funds
Interest-bearing assets

$72 \%$

$17 \%$

$72 \%$

$17 \%$

$73 \%$

$58 \%$

$34 \%$

$32 \%$

$16 \%$

$12 \%$

$2 \%$

$4 \%$

$31 \%$

$25 \%$

$19 \%$

$19 \%$

$10 \%$

$10 \%$

$8 \%$

$19 \%$

$8 \%$

$16 \%$

$12 \%$

$13 \%$

$7 \%$

$9 \%$

$2 \%$

$11 \%$

$7 \%$

$8 \%$

$9 \%$

$26 \%$

\section{As Percent of All Funds \\ Equity Funds, Total \\ Swedish equity funds \\ Regional/world equity funds \\ Country equity funds \\ Sectoral equity funds \\ Mixed funds \\ Generation funds \\ Interest-bearing assets \\ Default fund}

$50 \%$

$11 \%$

$23 \%$

$1 \%$

$13 \%$

$5 \%$

$13 \%$

$1 \%$

$31 \%$
$14 \%$

$3 \%$

$6 \%$

$1 \%$

$4 \%$

$1 \%$

$3 \%$

$1 \%$

$81 \%$
$12 \%$

$3 \%$

$5 \%$

$2 \%$

$3 \%$

$1 \%$

$2 \%$

$1 \%$

$84 \%$
$6 \%$

$1 \%$

$2 \%$

$1 \%$

$1 \%$

$1 \%$

$1 \%$

$3 \%$

$90 \%$

Source: PPM web site 


\section{TABLE 6. LARGEST FUNDS SELECTED IN EACH ROUND OF PREMIUM PENSION CHOICE, 2000-2003, INCLUDING DEFAULT FUND}

\begin{tabular}{|c|c|c|c|c|}
\hline Fund Name & Fund Manager & $\begin{array}{l}\text { Total \# of } \\
\text { Persons } \\
\text { Choosing }\end{array}$ & $\begin{array}{l}\text { Total Amount } \\
\text { Placed } \\
\text { (Swedish } \\
\text { Kronor) }\end{array}$ & $\begin{array}{l}\text { Average } \\
\text { Percentage }\end{array}$ \\
\hline \multicolumn{5}{|l|}{2004} \\
\hline Premium Savings Fund & $\begin{array}{l}\text { Sjunde AP-fonden } \\
\text { East Capital Asset Management }\end{array}$ & \multicolumn{2}{|c|}{$116857127,417,008.97$} & $\begin{array}{l}\text { N.A. } \\
\text { N.A. }\end{array}$ \\
\hline East Capital Russia Fund & $A B$ & 1377 & $715,079.25$ & \\
\hline $\begin{array}{l}\text { HQ Russia Fund } \\
\text { AMF Pensions Sweden } \\
\text { Fixed-Income Fund }\end{array}$ & HQ Fonder Sverige Aktiebolag & 1263 & $\begin{array}{l}613,804.38 \\
565,835.88\end{array}$ & $\begin{array}{l}8 \text { N.A. } \\
8 \text { N.A. }\end{array}$ \\
\hline $\begin{array}{l}\text { FIxed-Income Fund } \\
\text { AMF Pensions Balanced } \\
\text { Fund }\end{array}$ & AMF Pension Fondförvaltning $A B$ & 1005 & $\begin{array}{l}565,835.88 \\
465,710.85\end{array}$ & 85 N.A. \\
\hline $\begin{array}{l}\text { SPP Generation 80-tal } \\
\text { AMF Pensions Sweden } \\
\text { Stock Fund }\end{array}$ & AMF Pension Fondförvaltning $A B$ & 911 & $\begin{array}{l}406,851.91 \\
404,928.87\end{array}$ & $\begin{array}{l}1 \text { N.A. } \\
\text { N.A. }\end{array}$ \\
\hline $\begin{array}{l}\text { Didner \& Gerge Stock Fund } \\
\text { East Capital Baltic Fund }\end{array}$ & $\begin{array}{l}\text { Didner \& Gerge Fonder } A B \\
\text { East Capital Asset Management } \\
\text { AB }\end{array}$ & 784 & $\begin{array}{l}364,130.32 \\
331.787 .67\end{array}$ & \multirow{2}{*}{$\begin{array}{l}\text { N.A. } \\
\text { N.A. } \\
\text { N.A. }\end{array}$} \\
\hline $\begin{array}{l}\text { East Capital Baltic Fund } \\
\text { Nordea Premium Pension } \\
\text { Fund 1980-84 }\end{array}$ & Nordea Fonder AB & 614 & $\begin{array}{l}331,787.67 \\
300,213.76\end{array}$ & \\
\hline \multicolumn{5}{|l|}{2003} \\
\hline Premium Savings Fund & Sjunde AP-fonden & 137,589 & $150,388,876$ & 100.0 \\
\hline $\begin{array}{l}\text { Didner \& Gerge Stock Fund } \\
\text { AMF Pensions Sweden }\end{array}$ & Didner \& Gerge Fonder AB & 710 & 331,907 & 40.8 \\
\hline $\begin{array}{l}\text { Stock Fund } \\
\text { AMF Pensions Sweden }\end{array}$ & AMF Pension Fondförvaltning $A B$ & 673 & 318,626 & 44.8 \\
\hline $\begin{array}{l}\text { Fixed-Income Fund } \\
\text { Länsförsäkringar Real }\end{array}$ & $\begin{array}{l}\text { AMF Pension Fondförvaltning } A B \\
\text { Länsförsäkringar Fondförvaltning }\end{array}$ & 512 & 308,829 & 50.9 \\
\hline Estate Fund & $A B$ & 799 & 301,611 & 32.1 \\
\hline HQ Russia Fund & HQ Fonder Sverige Aktiebolag & 565 & 282,910 & 42.5 \\
\hline Roburs Stock Fund Pension & $\begin{array}{l}\text { Föreningssparbanken Fonder } A B \\
\text { Skagen Fondene/Stavanger }\end{array}$ & 444 & 282,166 & 61.1 \\
\hline SKAGEN Avkastning & Fondsforvaltning AS & 501 & 278,319 & 34.8 \\
\hline $\begin{array}{l}\text { Alfred Berg Bond Fund } \\
\text { Skandia Fond Real Income }\end{array}$ & Alfred Berg Fonder $\mathrm{AB}$ & 592 & 273,177 & 34.6 \\
\hline Fund & Skandia Fonder AB & 482 & 265,465 & 39.1 \\
\hline \multicolumn{5}{|l|}{2002} \\
\hline Premium Savings Fund & Sjunde AP-fonden & 167,239 & $179,961,060$ & 100.0 \\
\hline Didner \& Gerge Stock Fund & Didner \& Gerge Fonder AB & 3,633 & $1,927,547$ & 42.6 \\
\hline $\begin{array}{l}\text { HQ.SE Russia Fund } \\
\text { AMF Pensions Sweden }\end{array}$ & HQ.SE Fonder Sverige AB & 2,227 & $1,100,633$ & 43.6 \\
\hline $\begin{array}{l}\text { Stock Fund } \\
\text { Carnegie Fund Medical }\end{array}$ & $\begin{array}{l}\text { AMF Pension Fondförvaltning AB } \\
\text { Carnegie Fund Management }\end{array}$ & 1,727 & 760,219 & 39.8 \\
\hline Subfund & Company S A & 1,734 & 726,690 & 29.6 \\
\hline
\end{tabular}




\begin{tabular}{|c|c|c|c|c|}
\hline $\begin{array}{l}\text { Roburs Russia Fund } \\
\text { Pictet G.S.F Compartiment }\end{array}$ & Robur Fonder $A B$ & 1,610 & 698,907 & 37.9 \\
\hline Biotech & Pictet Global & 1,429 & 589,007 & 29.8 \\
\hline Carlson Fund Equity & Carlson Fund Management & & & \\
\hline American Small Cap & Company S.A Luxembourg & 1,576 & 588,150 & 28.5 \\
\hline $\begin{array}{l}\text { SPP Generation 70-Decade } \\
\text { Nordea Premium Pension }\end{array}$ & SPP Fonder AB & 858 & 547,850 & 44.7 \\
\hline Fund $1980-84$ & Nordea Fonder $\mathrm{AB}$ & 1,659 & 540,515 & 43.9 \\
\hline \multicolumn{5}{|l|}{2001} \\
\hline Premium Savings Fund & Sjunde AP-fonden & 405,300 & $540,810,584$ & 100.0 \\
\hline $\begin{array}{l}\text { Didner \& Gerge Stock Fund } \\
\text { AMF Pensions Sweden }\end{array}$ & Didner \& Gerge Fonder AB & 10,902 & $6,075,426$ & 38.8 \\
\hline Stock Fund & AMF Pension Fondförvaltning $A B$ & 7,123 & $4,652,406$ & 40.4 \\
\hline $\begin{array}{l}\text { Roburs Contura Stock Fund } \\
\text { AMF Pensions World Stock }\end{array}$ & Robur Fonder AB & 8,615 & $3,659,936$ & 29.9 \\
\hline $\begin{array}{l}\text { Fund } \\
\text { Pictet G.S.F Compartiment }\end{array}$ & AMF Pension Fondförvaltning AB & 6,164 & $3,645,867$ & 38.6 \\
\hline Biotech & Pictet Global & 7,866 & $3,629,006$ & 31.4 \\
\hline Roburs Pension Stock Fund & Föreningssparbanken Fonder $A B$ & 3,674 & $2,782,334$ & 49.9 \\
\hline $\begin{array}{l}\text { SPP Generation 70-Decade } \\
\text { AMF Pensions Balance }\end{array}$ & SPP Fonder $\mathrm{AB}$ & 4,121 & $2,660,314$ & 45.2 \\
\hline Fund & AMF Pension Fondförvaltning $A B$ & 3,613 & $2,608,661$ & 41.6 \\
\hline Roburs Medica Stock Fund & Föreningssparbanken Fonder $A B$ & 5,202 & $2,129,306$ & 29.3 \\
\hline \multicolumn{5}{|l|}{2000} \\
\hline Premium Savings Fund & Sjunde AP-fonden & \multicolumn{2}{|c|}{$1,550,12017,160,328,449$} & 100 \\
\hline $\begin{array}{l}\text { Roburs Contura Stock Fund } \\
\text { AMF Pensions World Stock }\end{array}$ & Robur Fonder AB & 665,309 & $2,254,849,783$ & 25.3 \\
\hline Fund & AMF Pension Fondförvaltning $A B$ & 377,021 & $1,812,419,823$ & 36.34 \\
\hline $\begin{array}{l}\text { Roburs Pension Stock Fund } \\
\text { AMF Pensions Sweden }\end{array}$ & Föreningssparbanken Fonder AB & 283,162 & $1,574,759,517$ & 42.01 \\
\hline Stock Fund & AMF Pension Fondförvaltning $A B$ & 320,460 & $1,286,971,918$ & 31.04 \\
\hline Didner \& Gerge Stock Fund & Didner \& Gerge Fonder AB & 306,201 & $1,146,886,229$ & 26.24 \\
\hline Roburs Medica Stock Fund & Föreningssparbanken Fonder $A B$ & 349,574 & $1,081,848,992$ & 23.74 \\
\hline SPP Generation 50-Decade & SPP Fonder $A B$ & 111,942 & $990,947,684$ & 49.97 \\
\hline $\begin{array}{l}\text { SPP Generation } 60 \text {-Decade } \\
\text { Carnegie Fund Medical }\end{array}$ & $\begin{array}{l}\text { SPP Fonder AB } \\
\text { Carnegie Fund Management }\end{array}$ & 131,025 & $938,366,174$ & 41.71 \\
\hline Subfund & Company S A & 237,691 & $776,134,749$ & 22.98 \\
\hline
\end{tabular}

N.A.=Not available

Source: PPM web site 


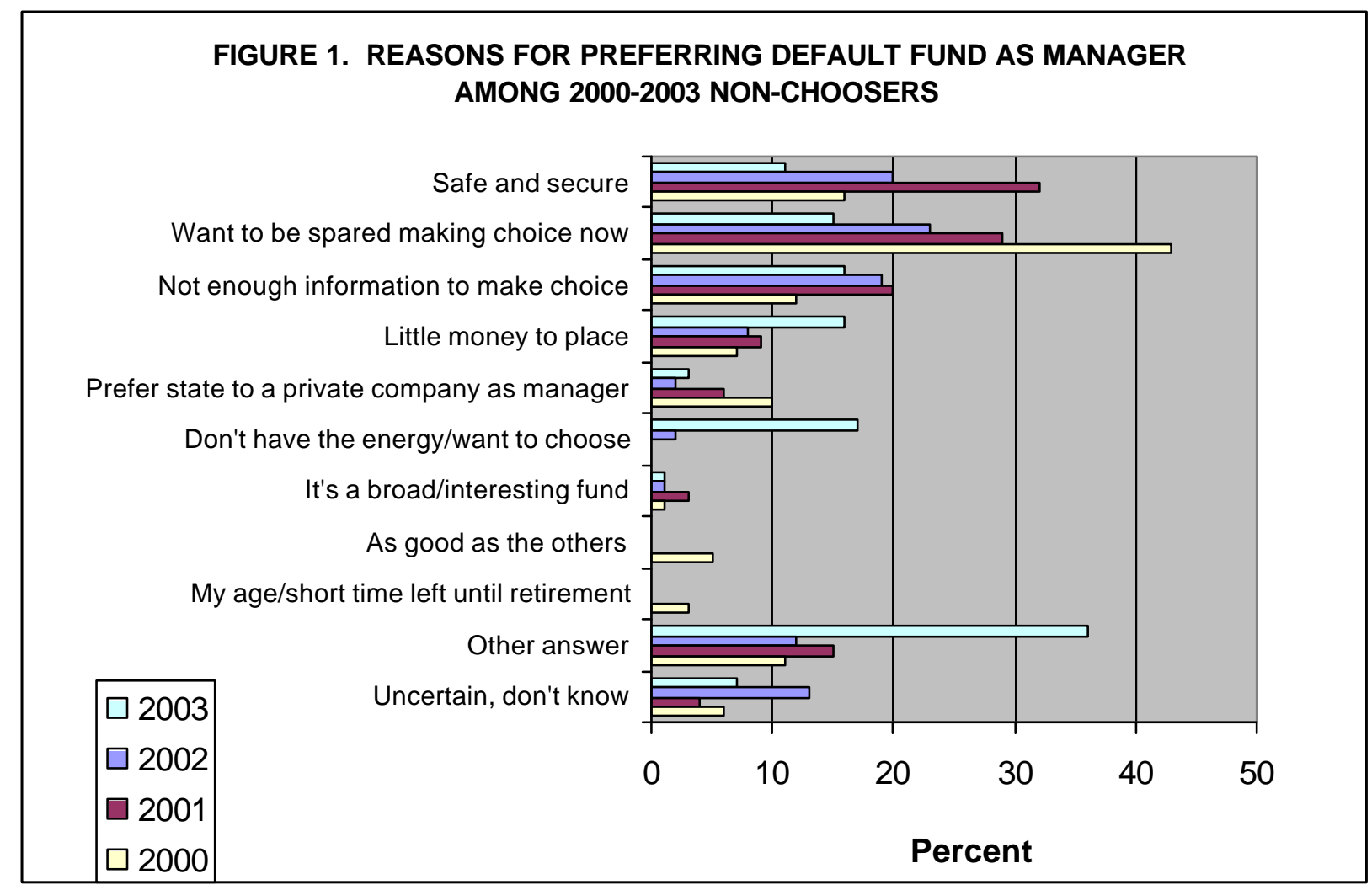

Question: "Why do you want the $7^{\text {th }}$ AP Fund to manage the funds?" Asked only of survey respondents who have said that they want the $7^{\text {th }}$ AP fund to invest for them.

Source: Sifo Research and Consulting, Eftervalundersökning avseende premiepensionsvalet, 2000, 2001; CMA AB, Eftervalsundersöknning 2003 [Post-Choice Survey, 2003], pp-34-35. 


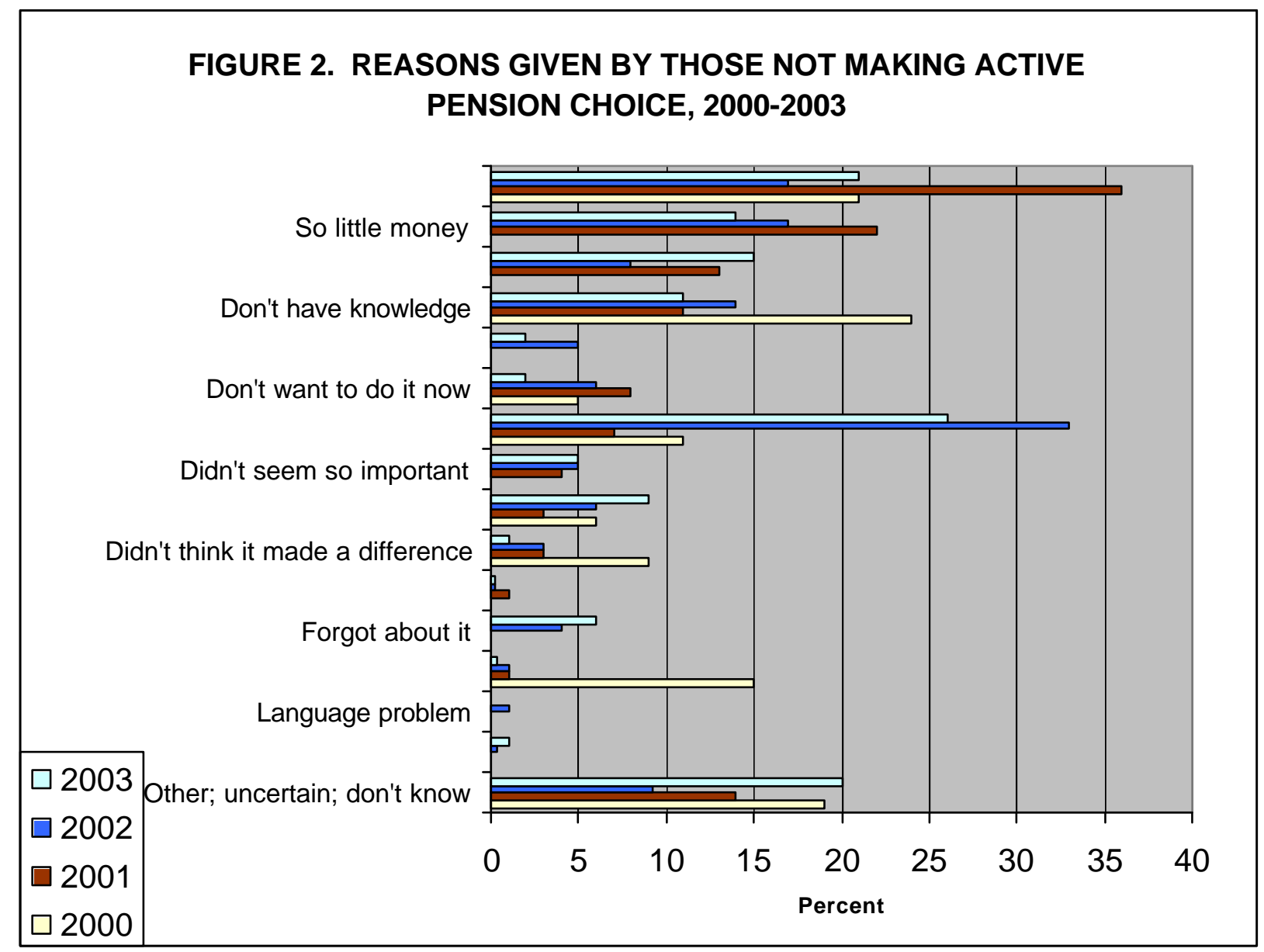




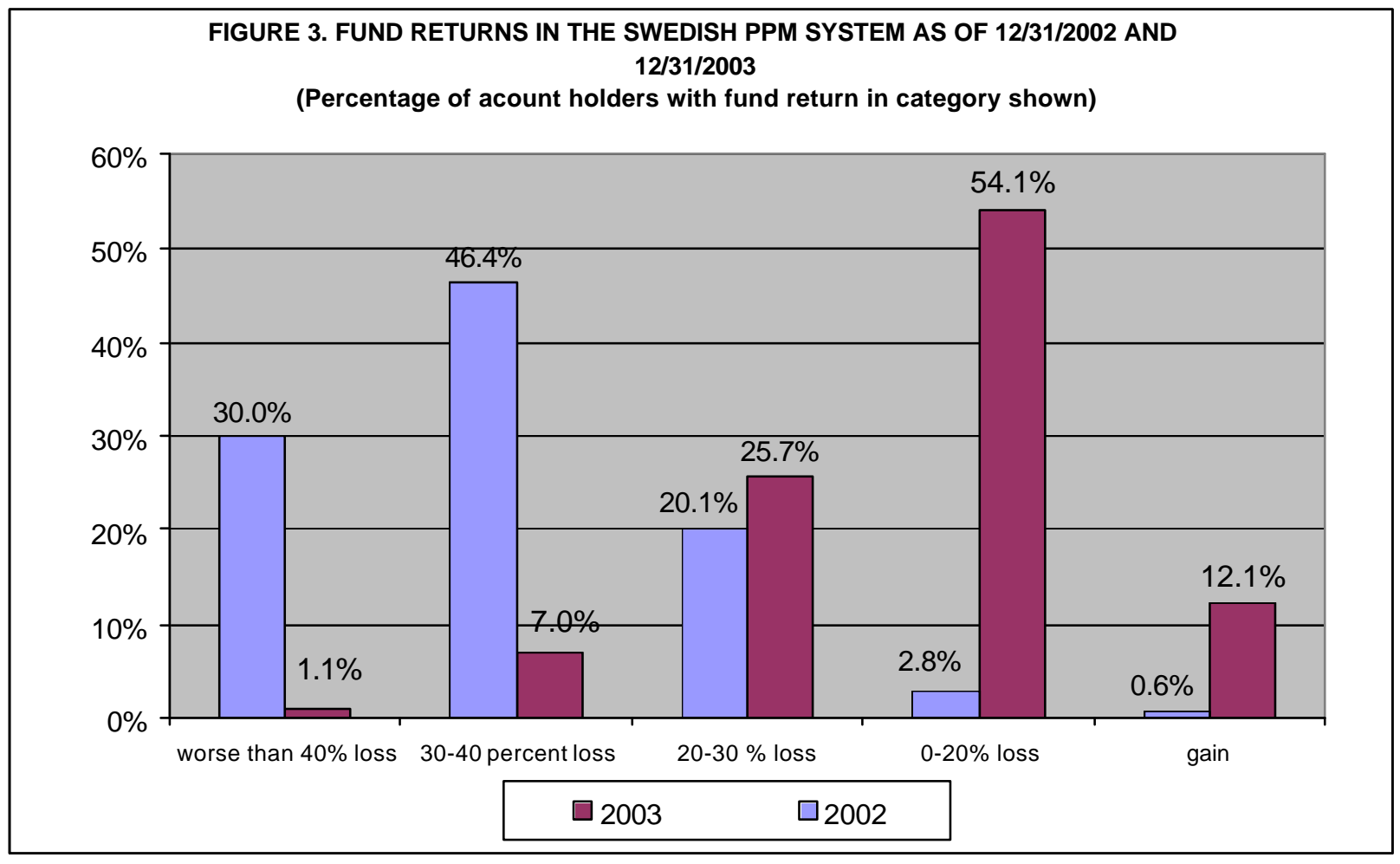




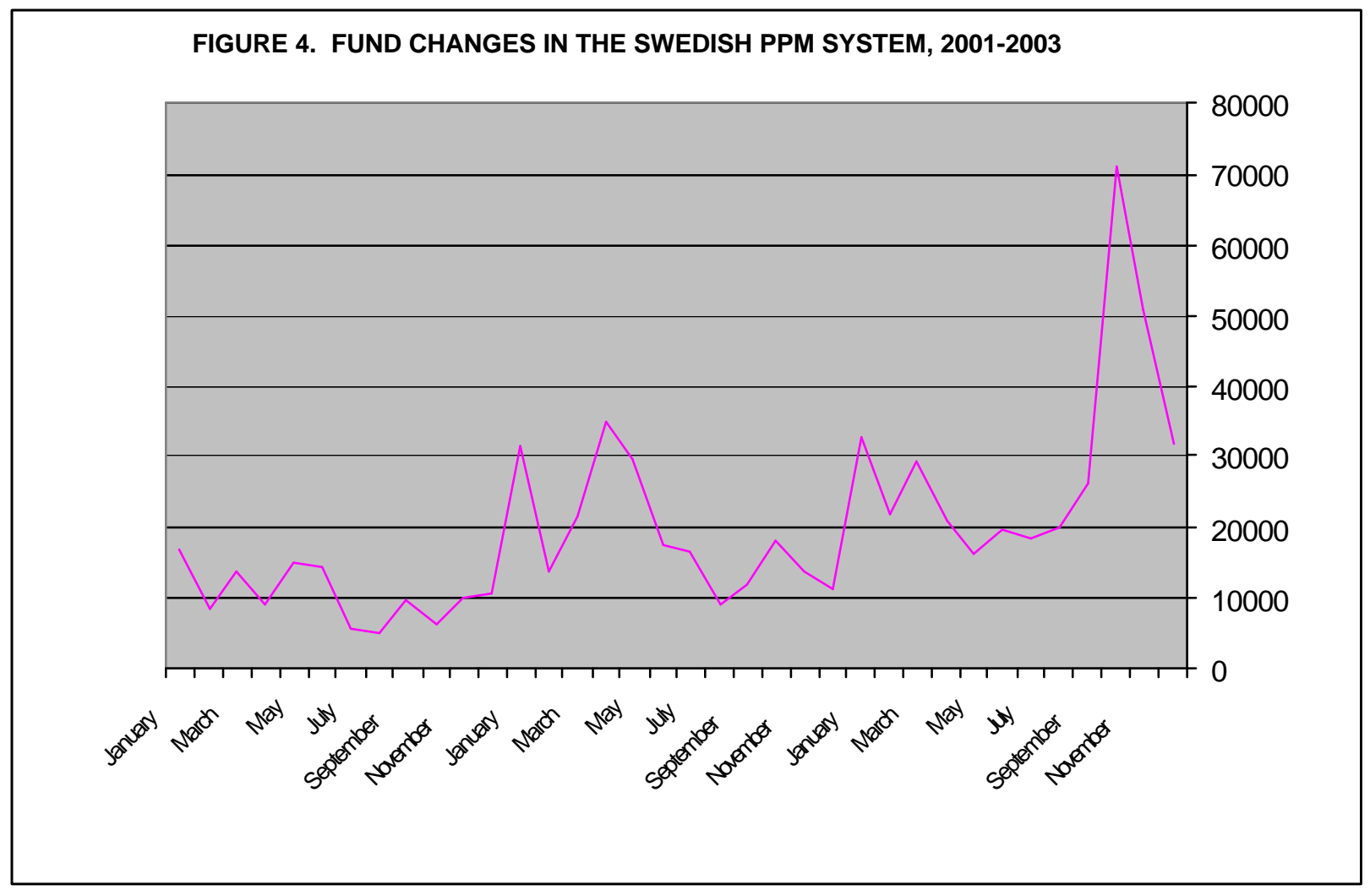




\section{RECENT WORKING PAPERS FROM THE \\ CENTER FOR RETIREMENT RESEARCH AT Boston COLLEGE}

Design and Implementation Issues in Swedish Individual Pension Accounts R. Kent Weaver, April 2005

Understanding Expenditure Patterns in Retirement

Barbara A. Butrica, Joshua H. Goldwyn, and Richard W. Johnson, January 2005

Lashed to the Mast?: The Politics of Notional Defined Contribution Pension Reforms

Sarah Brooks and R. Kent Weaver, January 2005

Changes in the Distribution of Long-Run Earnings and Retirement IncomesHave Recent Cohorts Fallen Behind?

Peter Gottschalk and Minh Huynh, January 2005

The Age Profile of Income and the Burden of Unfunded Transfers in Four Countries: Evidence from the Luxembourg Income Study

Gary Burtless, December 2004

Projecting Immigration: A Survey of the Current State of Practice and Theory Neil Howe and Richard Jackson, December 2004

Nonearnings Income Migration in the United States: Anticipating the Geographical Impacts of Baby Boom Retirement

Peter B. Nelson, December 2004

Does Work Pay at Older Ages?

Barbara A. Butrica, Richard W. Johnson, Karen E. Smith, and Eugene Steuerle, November 2004

Poverty and Income Maintenance in Old Age: A Cross-National View of Low Income Older Women

Timothy M. Smeeding and Susanna Sandstrom, November 2004

How Does Marriage Affect the Allocation of Assets in Women's Defined Contribution Plans?

Angela C. Lyons and Tansel Yilmazer, November 2004

All working papers are available on the Center for Retirement Research website (http://www.bc.edu/crr) and can be requested by e- mail (crr@bc.edu) or phone (617-5520191). 